\title{
Development of a model regional emergency response plan for a mining town: The case of Bindura, Zimbabwe.
}

\author{
N. Mudavanhu ${ }^{*}$, C. Mudavanhu' ${ }^{2}$, P. Dzomba ${ }^{1}$, F. Kausiyo ${ }^{3}$, T.D. Mushore ${ }^{2}$ and \\ T.P. Chinyanganya ${ }^{2}$. \\ ${ }^{1}$ Chemistry Department, Bindura University Of Science Education, Zimbabwe \\ ${ }^{2}$ Geography Department, Bindura University Of Science Education, Zimbabwe \\ ${ }^{3}$ Health Science Department, Bindura University Of Science Education, Zimbabwe
}

\begin{abstract}
A}$ case study was carried out in order to develop a model regional emergency response plan for a mining town. Interviews were used to collect data on available emergency response structures and resources for both the town and within various organizations. A questionnaire was used to explore risk perceptions, communication, preparedness and adequacy of current emergency response scenario. This was complemented by site observations using a guide and data sheets. Document analysis of individual emergency response plans (where available) was also done. Results show that the development of the town has not been accompanied with emergency response planning. The Municipality does not have a functioning emergency response center and equipment. This puts the community at serious risk in the event of fire, mine collapse, toxic release and even a natural disaster. The results indicate that individual response plans within various institutions may fail during a major accident. This is because of preoccupation with their core business and lack of technical expertise required for a successful evacuation, escape and rescue. Most developing countries towns do not have an emergency response plan this puts the workers, the environment and inhabitants at serious risk of injury or contamination. A model emergency plan is proposed outlining the duties of each local institution. The model has been designed to enable risk analysis and worst case scenarios in order to make plans that minimize loss and environmental contamination. Results also show that expertise and resources for the plan can be mobilized from local institutions such as the municipality, police, medical institutions, the mines and universities. Local government, industry and communities need to develop an emergency response plan as a core part of their business and functionality.
\end{abstract}

Keywords - Accidents, Emergency response plan, Risk analysis, Environmental management, Toxic release.

Submitted Date 21 June 2013

Accepted Date: 26 June 2013

\section{Introduction}

Emergency planning is a significant part of safety management which is usually not well applied in many cases [1]. Large technological installations and huge settlements increase the risk of serious accidents. As towns evolve, shared risk management is important to cater for these accidents. It has been proven that despite a company's best efforts, accidents and in particular catastrophic events cannot be avoided and they occur unexpectedly over their lifetimes [1;2]. Major industrial accidents and catastrophic events, especially fire, explosion or environmental poisoning in communities, may cause great losses [3]. The loss may be due to property damage, loss of life and contamination of the environment. Loss of lives can be prevented by proper planning for evacuation, escape and rescue. According to [4] evacuation refers to the planned method of leaving the installation without directly being exposed to the dangerous situation, while escape is the process of leaving the installation in an emergency when the evacuation system has failed. Rescue is the process of recovering of persons following their evacuation or escape from or near the installation. Some of the hazards which can potentially lead to loss and hence require mitigation in the form of evacuation, escape and rescue are : blowouts, process leaks, utility areas and systems fires and explosions, fire in accommodation areas, structural collapse, loss of installation stability/position and extreme weather [4]

Being prepared with a plan facilitates the readiness to react without delay [2]. Significant efforts must be made to predict these potential abnormal events and also to provide a design which facilitates prevention, early detection and recovery from these scenarios [3].

An emergency encompasses a more general period during which an extraordinary situation exists in which there is deterioration in the coping abilities of a group or community, or coping abilities can only be sustained by extraordinary measures taken by the community or through external assistance [5]. An emergency plan is a formally written plan or group of procedures to be implemented in case of a catastrophic event situation involving communication, planning, action, risk analysis, operational support, logistic support and whatever is 
necessary to reduce accident impacts. [1;6]. This plan describes how such accidents and their consequences should be handled both on- and off company premises. In order to ensure rapid, orderly and effective implementation of emergency and rescue actions, emergency plan is usually pre-established [3]. According to [1] there are three emergency levels - individual, regional and national. An individual emergence response plan (ERP) is required for industries which have dangerous processes that in the case of accidents can cause serious damage to employees or the environment. This is usually applied by most organizations as part of their occupational safety and health (OSH) programs for the protection of their workers, environment and communities. A regional and national emergency plans covers all individual emergency plans in a specific area in order to respond to an emergency situation when an individual emergency plan is not enough to respond and control the situation.

Bindura like most developing African towns', growth is driven by further industrialization of a once mine dormitory community to a city with commercial business district, schools, industrial areas (mostly small and medium enterprises - SMEs), police camps, prisons, hospitals and universities. Town development is usually accompanied by safety considerations. As the town grows further, some of these considerations are relaxed. As a result large enterprises (LEs) such as mines have comprehensive OSH programs, while the municipality and surrounding SMEs lag behind seriously. This puts the whole town at serious risk. Though the LEs may have adequate emergency response expertise and resources for their workers they constitute only a portion of the town's population. If a situation arises where their emergency response is overwhelmed they have nowhere to turn to and also if the community requires their resources they cannot cope. This scenario makes the town unprepared for major and catastrophic situations. Research in Europe, America, Australia and India presents well-resourced municipal or government agencies which act as coordinators in ER activities. In most African towns the municipal council hardly has resources and expertise for their residents let alone to coordinate ER for the whole town. As a result a different approach is needed to manage ER activities in such towns.

In Zimbabwe, the Department of Civil Protection (DCP) is the main body tasked with the responsibility of setting up emergency management plans. The Department is currently housed within the Ministry of Local Government, Rural and Urban Development (MLGRUP) [7]. Figure 1 illustrates the structure of Zimbabwe's Emergency Management System. The department is also responsible for coordinating the training of civil protection officers, at government - the national, provincial, and district levels [8; 7]. These together with the various government, private and non-governmental institutions form Response Partners (RPs) that are required to plan for disasters by producing operational plans for emergency preparedness and response [8]. Including these institutions greatly enhances capacity building and promotes inter organization extension services.

This paper proceeds by trying to answer the following questions: How has the town responded in the past? Will the town be able to contain a major toxic release and protect the environment? What will happen if one mine collapses? Can people escape, be rescued or evacuated in case of a fire at one of the institutions such as hospital, prison, boarding school or university hostel? What type of plan would suit local situation and structures? This paper presents the current emergency response scenario of the town and its implications on the safety of residents. Examples of past incidents, accidents and disasters and how they were handled are given. The paper gives an inventory of the locally available expertise and resources and what needs to be acquired or established for basic ER activities. Finally an ERP for the town is proposed and discussed.

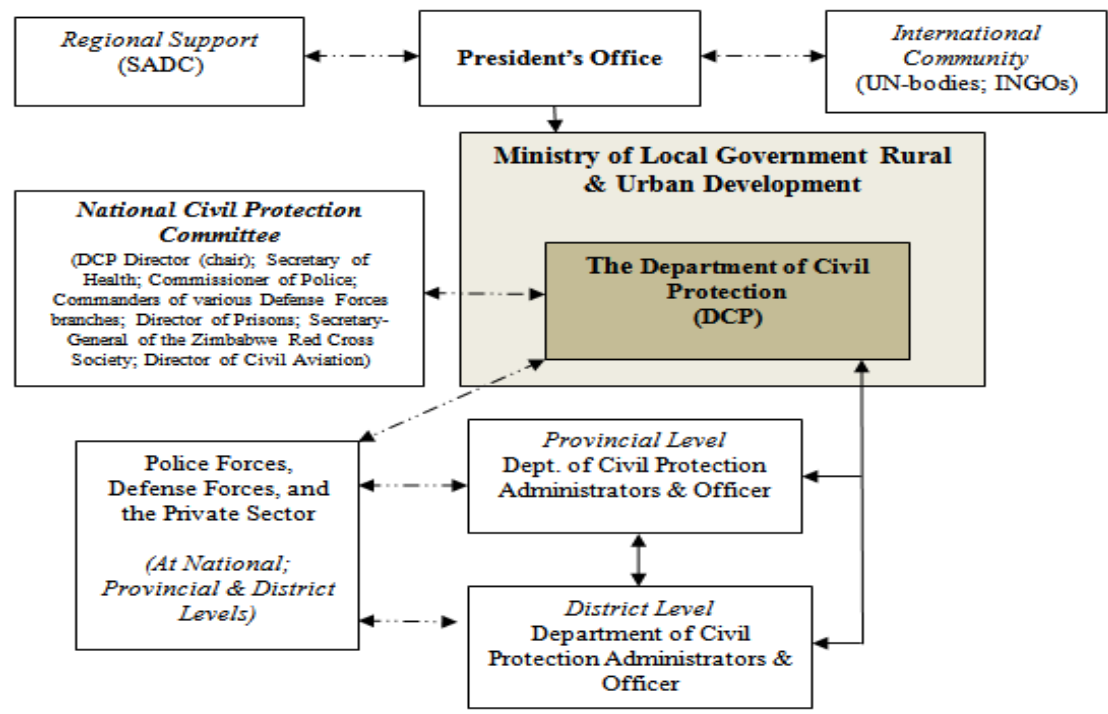

Fig. 1 The Structure of Zimbabwe's Emergency Management System [7]. 


\subsection{Research Instruments}

\section{Methodology}

Information was collected mainly through interviews with representatives of different organizations such as municipal council officers, hospital superintendents, police, university security and student welfare, etc. This was used to collect data on available emergency response structures and resources for both local community and within various organizations. A questionnaire was used to explore risk perceptions, trust, communication, preparedness and adequacy of current emergency response scenario. This was complemented by site visit observations using a guide and data sheets. Individual organizations were asked to provide information on their own resources that may be available for an emergency plan. A document analysis of individual emergency response plans (where available) were also analyzed.

\section{Questionnaire items}

Table 1 Questionnaire items for Institutions

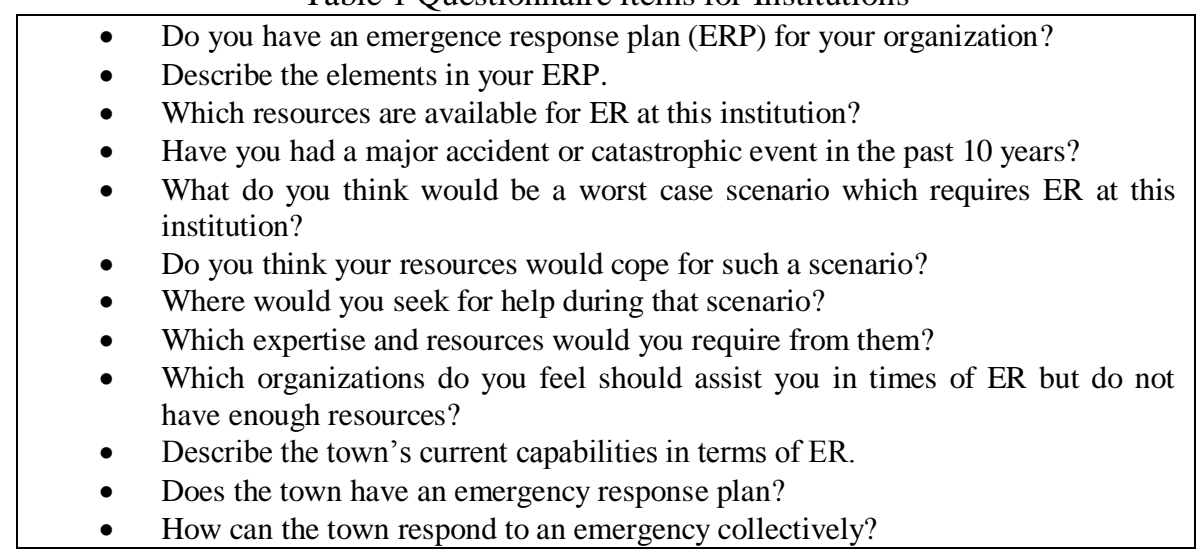

\subsection{Study Area}

Figure 2 shows the map of Bindura town. The map also shows the locations of various institutions. The map shows the CBD, industrial areas, residential areas, schools, clinics, mines, police stations, streams, a river and main transport routes.

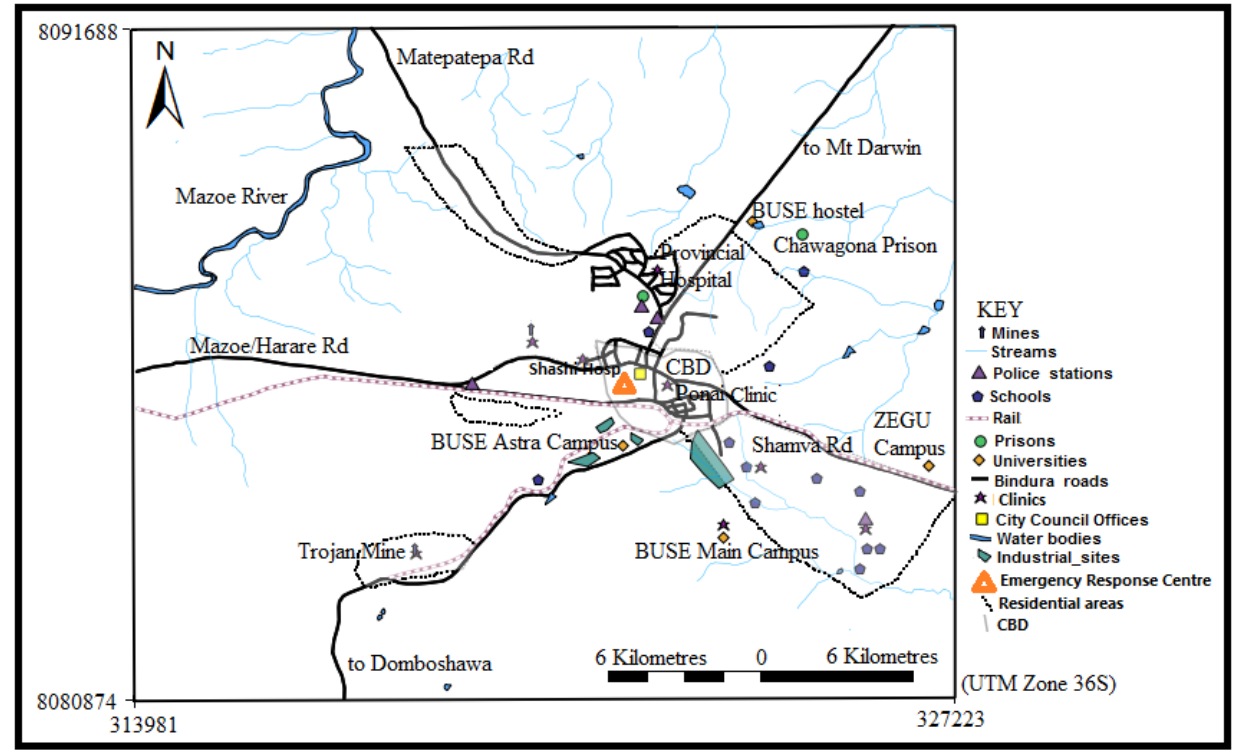

Fig. 2 Map of Bindura Town

\section{Results and Discussion}

3.1 Some Incidents that required Emergency Response in Bindura.

\section{Incident 1.}

In the evening of 10 May 2006 a building housing the works department and reprographic department of the Bindura University of Science Education (BUSE) caught fire and computers, university records, furniture and stationery worth thousands of US dollars were destroyed. University authorities reported that the 
Development of a model regional emergency response plan for a mining town: The case of Bindura,

firefighting crew vehicle arrived on the scene about 30 minutes later without water and faulty equipment. No formal investigation was done by local government to ascertain the cause of the fire. The emergency response capability of the fire department was inadequate and resulted in serious losses.

\section{Incident 2}

During the night of 3 August 2010, a university house caught fire at around 2015pm. A neighbor who happened to be the Provincial Governor of Mashonaland Central Province phoned the fire brigade at around 2020. It is reported that the two firefighters arrived at the scene in a Renault JE15 fire tender without water at about 2025. They are reported to have rushed to a nearest hydrant which had no water. Water is rationed by the city council and is usually turned off around $1945-2000 \mathrm{pm}$. They had to rush back to town (about $7 \mathrm{~km}$ ) to fetch water. When they returned moments later, the roof of the house had already collapsed. Nothing was saved from the house. The house was burn to ground level and the damage was estimated to be around US40000 dollars. The firefighting crew once again demonstrated lack of preparedness. Not being ready for people who are employed to do a task implies negligence or lack of training. The university security department suggests that the firefighting equipment needs serious servicing or replacement.

\section{Incident 3.}

On 20 February 2012 the confirmed case of typhoid is reported to the Provincial Medical Director (PMD) at Bindura Hospital. A suspected typhoid outbreak was looming over the town. The PMD called a nongovernmental organization (NGO), International Medical Corps (IMC) and an emergence response meeting was held by the Ministry of Health $(\mathrm{MoH})$ and the NGO. Through the support of European Commission, IMC mobilized resources to treat the rising cases, mitigate the spread and educate the community. With the help of $\mathrm{MoH}$, IMC lead a field investigation team and traced the source of contamination to a shallow well near a broken sewer pipes in the suburbs. On the third day the $\mathrm{MoH}$ had to set up isolation camps as reported cases rose to 11. Sewer pipes repair was initiated to prevent further contamination of the community. Distribution of water tablets and typhoid education was also started in the 14 schools (with about 11000 students) in and around Bindura by the IMC. By the $4^{\text {th }}$ day 17 cases had been reported. By day five public health officers and community volunteers trained on the $4^{\text {th }}$ day intensified education in schools and the door to door distribution of sanitation tablets. A total of 8500 household were reached. Unblocking of sewer pipes continued. By the $6^{\text {th }}$ day 22 cases had been reported and rose to 27 on the $7^{\text {th }}$ day. In week two the number of new cases taped off as mitigation intensified and was later declared under control in the third week. Typhoid occurs when water and food source get contaminated and is directly attributed to water and sanitation problems. Without the IMC the disaster could have been worse. If an emergency response plan was available for the district more institutions and resource could have been availed and the number of cases would have been reduced. The town benefited from the emergency response plan of a local NGO. [9].Up until today the Bindura community continues to struggle with sewer bursts and leaks, a major environmental hazard.

\section{Incident 4.}

On the $4^{\text {th }}$ of February 2013 a heavy rain storm hit the Bindura town community. This storm resulted in a tower light falling onto a house destroying the house and blocking a road for over 24 hours. The storm destroyed property as buildings collapsed, rooftops were blown and trees fell. Flooding due to poor drainage blocked roads for about 18 hours after the storm. No emergency response plan was activated to assist affected people and no post disaster assessment was done to ascertain the damage by the storm and if people were injured. This gives an indication that there is no risk analysis being done in the town to protect the residents and environment. When flooding occurs it increases contamination of the environment and water sources. Sewage from burst pipes and mercury from small scale and illegal gold mining, a common feature in Chipadze suburb can be spread by flooding. This poses disease outbreak and serious heavy metal poisoning to the residence.

\section{Incident 5.}

On morning of February 14, 2013 a 1000 $\mathrm{m}^{3}$ leach tanks collapsed onto similar neighbouring tank at one of the local mines. This caused structural damage to the two tanks and a discharge of slurry with ore, cyanide and charcoal onto the ground surrounding the leach tanks beyond the banded containment area. The accident raised serious concerns for safety and health of its employees on site and members of the local community. It is reported that five employees were affected by the incident hospitalized and released. According to an article in the mine news release website [10], the local community and Government agencies co-operated in clean-up operations. The mine inspectorate did the site investigation and the Environmental Management Authority monitored the discharge levels in the mine drainage canal soon after the accident. According to the [11] (a local newspaper) of 21 February 2013 the Environmental Management Agency (EMA) fined the mine USD\$5 000 for the cyanide spillage. This is an application of the polluter pays principle, which causes most LEs 
to an extent "afford polluting". Following the spillage incident, EMA gave the gold mine conditions to contain the discharge failure of which the mining concern would be forced to close down operations. A few days later permission to resume operations was given. Besides huge amounts of cyanide in the 3 leaching, 8 absorption and 3 eluent tanks (total capacity of approximately $12000 \mathrm{~m}^{3}$ ) the company also stores a large stock of sodium cyanide. Keeping or using large inventory of toxic materials is a major risk factor. Cyanide salts are among the most rapidly acting of all known poisons because of its affinity for metals. Cyanide is a potent inhibitor of respiration, acting on mitochondrial cytochrome oxidase and hence blocking electron transport. This results in decreased oxidative metabolism and oxygen utilization. Lactic acidosis then occurs as a consequence of anaerobic metabolism [12]. Accident investigation findings were not made public. There is no report of the involvement of local government in emergency response. The national newspaper on 21 February did not give detailed information of health and environmental risks of cyanide release to the environment. The Municipality did not alert the community of the accident

\subsection{Current ER scenario for Bindura}

Results show that the development of the town has not been accompanied with emergency response in case of a major disaster. Though the MLGRUP has a Provincial and District civil protection structures, they are not functional. The structures have not been able to come up with an ERP and to meet regularly and perform their various duties. Functions of area civil protection officers are listed in [8] as

(a) The establishment, maintenance and command of civil protection organizations;

(b) The provision, operation and co-ordination of all civil protection services and activities connected with civil protection;

(c) Giving such orders and taking such measures, during a state of disaster, as in his opinion are reasonably necessary in order to deal with such state of disaster;

(d) co-ordinating the use of materials and services made available by government ministries, local authorities, statutory bodies and other organizations during a state of disaster;

(e) The preparation of reports on civil protection generally in his civil protection area whenever he is required to do so by the provincial civil protection officer [8].

According to the same act the Director of the DCP may from time to time appoint planning committees for the preparation of plans in respect of any aspect of civil protection, in any civil protection province or in any civil protection area. This has not happened for Bindura yet the town faces serious hazards for workers, the community and environment. The Municipal council and hence the town does not have a functioning emergency response equipment and center. This puts the community at serious risk in the event of a major accident such as fire, mine collapse and toxic release. Though private organizations may have individual emergency response plans, the DCP structures should complement them and help enforce civil protection. Without this help, when disaster strikes individual response plans within various institutions may be overwhelmed and fail due to preoccupation with their core business and lack technical expertise required for a successful evacuation, escape and rescue [4]. Information collected from various institutions in the town however show that expertise and resources can be mobilized from the municipality, police, medical institutions, the mines and university to constitute an emergency plan. This provision is given in the Civil Protection Act. Table 2 gives the expertise and resources available for ER in Bindura.

The layout of these institutions is given in Fig. 2. Most RPs are located northwest of the CBD except the city council and the District Administrator's (DA) office which are in the CBD. The DA according to the DCP structure heads the DEA with the help of RPs.

The Municipality firefighting department, an important RP is housed near the City council headquarters. The firefighting trucks are old and their functionality is quite questionable. Due to shortage of vehicles in the local authority the vehicles are used as announcement vehicles and for errands. This compromises ER for the town in that it cannot be guaranteed that when an emergency occurs the trucks will be ready. Because of these various other uses the trucks do not always have water. During some emergencies the trucks have proceeded to accident sites without water. This is also worsened by the fact that the town does not have emergency numbers and an emergency control center. 
Table 2. The resources that may be available for emergency response.

\begin{tabular}{|c|c|c|c|}
\hline & Institution & Expertise available & Resources available \\
\hline 1 & $\begin{array}{l}\text { Bindura University Of } \\
\text { Science Education }\end{array}$ & $\begin{array}{ll}\text { - } & \text { Health and } \\
& \text { counseling specialists } \\
\text { - } & \text { Safety specialists } \\
\text { - } & \text { Environmental } \\
& \text { management and } \\
\text { - } & \text { pollution specialist } \\
\text { - } & \text { Disalytical Chemists } \\
& \text { specialist management } \\
\text { - } & \text { GIS and remote } \\
& \text { sensing specialists } \\
\end{array}$ & $\begin{array}{ll}\text { - } & 4 \text { Busses } \\
\text { - } & \text { Clinic } \\
\text { - } & \text { Lecture rooms } \\
\text { - } & \text { Ambulance } \\
\text { - } & \text { Laboratories }\end{array}$ \\
\hline 2 & Fredda Rebecca Mine & $\begin{array}{ll}- & \text { Mining specialist } \\
- & \text { Chemical engineers } \\
\text { - } & \text { Occupational health } \\
& \text { and safety specialist } \\
\end{array}$ & $\begin{array}{ll}- & \text { Industrial clinic } \\
\text { - } & 2 \text { ambulances }\end{array}$ \\
\hline 3 & Trojan Nickel mine & $\begin{array}{ll}- & \text { Mining specialist } \\
\text { - } & \text { Chemical engineers } \\
\text { - } & \text { Occupational health } \\
& \text { and safety specialists }\end{array}$ & $\begin{array}{ll}- & 2 \text { buses } \\
- & \text { Industrial clinic } \\
\text { - } & 2 \text { ambulances } \\
\text { - } & \text { School class rooms }\end{array}$ \\
\hline 4 & Bindura Municipality & $\begin{array}{ll}\text { - } & \text { Civil engineering } \\
\text { specialists } & \\
\text { - } & \text { Town planning } \\
\text { specialist } & \end{array}$ & $\begin{array}{l}\text { - } 2 \text { firefighting vans } \\
\text { - } \quad 2 \text { clinics } \\
\text { - } \quad 2 \text { ambulances }\end{array}$ \\
\hline 5 & Bindura Hospital & $\begin{array}{ll}- & \text { Medical specialists } \\
\text { - } & \text { Nursing specialist } \\
\text { - } & \text { Environmental health } \\
& \text { specialists }\end{array}$ & $\begin{array}{ll}- & \text { One ambulance } \\
- & 2 \text { other vehicles } \\
- & \text { Bed capacity of } 186 \\
- & \text { High dependency unit }-3 \\
\text { beds } \\
\text { Twin main theater and } \\
\text { small theater. }\end{array}$ \\
\hline 6 & Shashi View Hospital & $\begin{array}{ll}\text { - } & \text { Medical specialists } \\
\text { - } & \text { Nursing specialist }\end{array}$ & 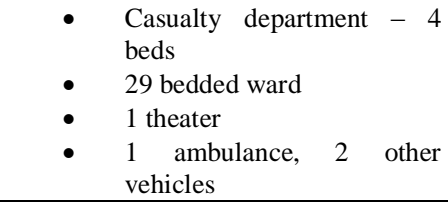 \\
\hline 7 & $\begin{array}{l}\text { Zimbabwe Republic } \\
\text { Police }\end{array}$ & $\begin{array}{l}\text { - Law and order is } \\
\text { maintenance } \\
\text { specialist (incl. routes } \\
\text { and restrictions) } \\
\text { Evacuation and } \\
\text { liaison specialists }\end{array}$ & \begin{tabular}{ll} 
- & \multicolumn{2}{l}{ Logistics cars } \\
- & Wireless communication \\
radio \\
- Accident scene marking \\
equipment
\end{tabular} \\
\hline 8 & $\begin{array}{l}\text { Ministry of Education } \\
\text { (Schools) }\end{array}$ & $\begin{array}{ll}- & \text { Education } \\
- & \text { Information } \\
& \text { dissemination } \\
\end{array}$ & $\begin{array}{l}\text { - Shelter for the evacuated } \\
\text { and rescued } \\
\text { - } 2 \text { Buses }\end{array}$ \\
\hline 9 & $\begin{array}{l}\text { Emergency } \quad \text { Medical } \\
\text { Rescue } \quad \text { Ambulance } \\
\text { Services (EMRAS) }\end{array}$ & $\begin{array}{ll}\text { - } & \text { Medical Services } \\
\text { - } & \text { Ambulance services } \\
\text { - } & \text { Emergency response } \\
\text { and care }\end{array}$ & $\begin{array}{l}\text { - } 1 \text { Ambulances } \\
\text { - } \quad \text { Two Medical Emergency } \\
\text { response technicians }\end{array}$ \\
\hline
\end{tabular}

Table 2 shows that the town has a total of nine (10) ambulances, two (2) industrial and 3 community clinics, 12 schools, 8 buses, 215 hospital beds etc., it indicates the resources that may be mobilized in times of crisis. Though these resources are privately owned and will be preoccupied with their day to day business, proper organization may make them to cooperate and avail resources and expertise. Since some of the institutions are partners in the DCP local structures and that the other organizations can be coopted as advising or assisting partners makes the town have vast resources for emergency response.

3.3 Development of the Regional Emergency Response plan (RERP)

From the available DCP structure, resources and expertise available locally a model emergency response plan can be as shown in Figure 4. 


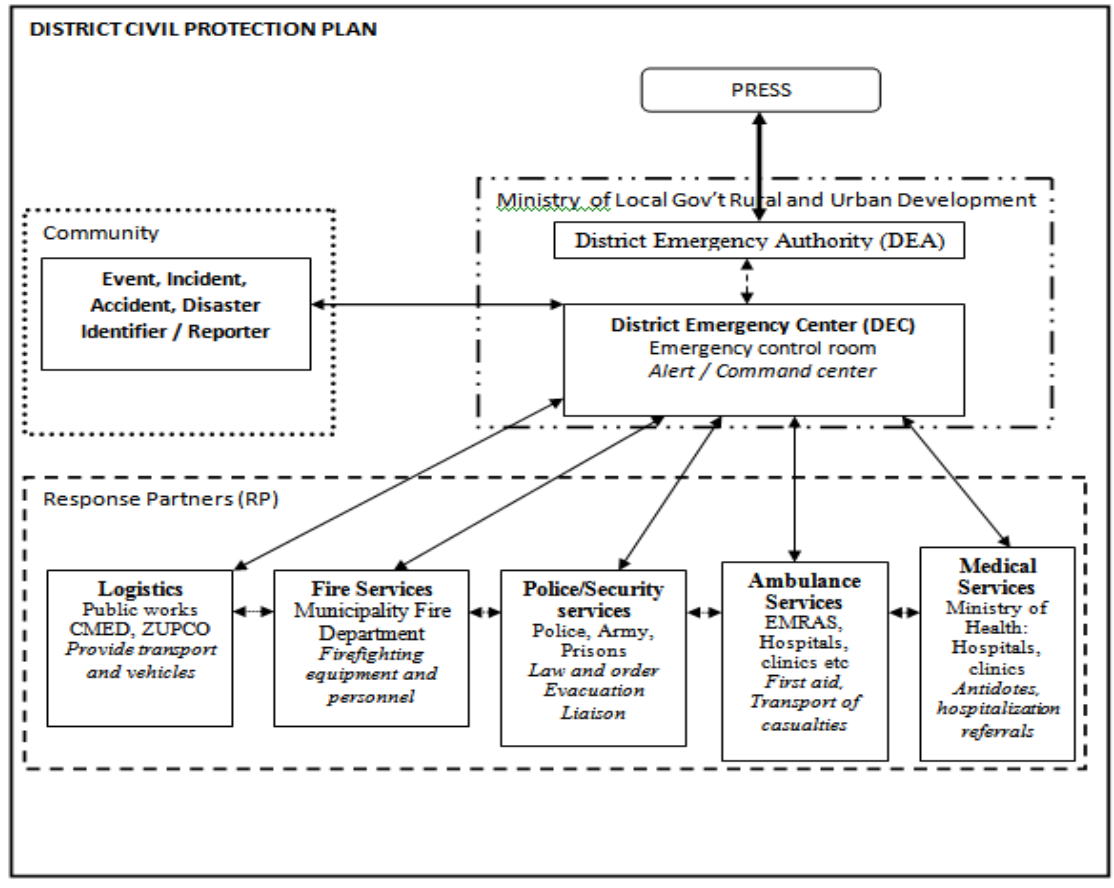

Fig. 3. Outline of a model ERP for Bindura Town.

The model suggests the establishment of the following:

- District Emergency Authority [6] that may be headed by District Administrator and comprising other DCP Administrators \& Officer [8] by the MLGRUP.

- Emergency Center and relevant personnel and equipment required for control center.

- An easily accessible toll free number which the community should be able to use to reach the control room.

- A committee of RPs that should have DCP terms of reference and operational strategy.

- Training of RPs and stakeholders in disaster management (including community education), emergency activities and drills by DEA.

- Systematic enforcement of ER policy in the district.

The model suggests that upon noticing an accident, disaster or catastrophic event, the incident identifier would contact the Emergency Control Room using a toll free number like 911. The operator in the control room using standard operating procedures given to him by the DEA would contact an appropriate Response Partners (RPs). Examples of RPs are given but not limited to those given in Fig.3. The RPs contacted should proceed to the accident scene and initiate response activities such as containing the situation, evacuation, escape or rescue. The DEA should be notified of the event and the action that has been taken so far. For response activities to be effective there should be quality communication between the RPs [13]. Duties of the various RPs are outlined but not limited to those given in Fig. 3. According to the nature of the emergency an officer from the DEA or one of the RPs as directed by DEA should assume the position of Onsite Response Coordinator (ORC) to ensure effectiveness and order. The ORC and representatives from RPs should agree on priority of response activities. This ensures that a coordinated approach is used without contradictions and clashes. Contradictions and clashes may lead to confusion and errors. Errors may be fatal since all tasks will be carried out under extreme circumstances and in a harsh or even hazardous physical environment [3]. Fatality of errors would be to both the RPs and victims. For example during the Chernobyl disaster in 1986 firefighters became the first victims because did not know that they were dealing with a radioactive explosion and were not protected against radioactive radiation [14]. If the accident or event has occurred at an institution the personnel from the institution should brief the ORC with relevant information such as the causes, extend and nature of the accident. Using this information the coordinator may mobilize relevant expertise from the response partners or other institutions in the town such as the Universities, Environmental Management Agency (EMA), National Social Security Authority (NSSA), Forestry Commission etc. as required containing the situation or for best strategies and precautionary measures needed to deal with the situation.

When satisfied with the evacuation, escape and rescue activities, the ORC after liaising with DEA may end the activities. Before ending response activities an accountability check on all individuals who were on site of the disaster an estimation of the severity of damage should be done. On successful completion of response activities a committee of the RPs, representatives of the DEA and relevant stakeholders should do a debrief [6] 
Development of a model regional emergency response plan for a mining town: The case of Bindura,

and suggest a recovery plan. If the DEA is unable to cope or contain the emergency at district level, they notify the provincial DCP structure. If the Provincial DCP is also unable to contain the situation they notify the National DCP structure. A national disaster is declared and more resources are mobilized as illustrated in Fig.1. However the implementation of the national plan would also involves the RPs as shown in Fig. 3. A recovery plan would involve a cleanup, pollution monitoring, neutralizing any hazardous materials, damage assessment etc. The DEA or whoever they task should handle press and publicity issues. A plan on stages that must be fulfilled before normalcy can be declared is needed; it would clearly indicate all conditions that must be met. A review of the response activities and plan is made and updated. A record of all that transpired is kept at the DEA.

\section{CONCLUSION}

Towns, industrial clusters and communities in most developing countries especially in Africa do not have emergency responds plans even when resources for one can be mobilized locally. This puts the workers, the environment and inhabitants at serious risk of injury or contamination. Town development should be accompanied by risk analysis and development of worst case scenarios in order to make plans that minimize loss and environmental contamination when a catastrophic event strikes. Local government, industry and communities need to develop an emergency response plan as a core part of their business and functionality. Local government through municipal councils and all RPs need to mainstream disaster risk reduction in development projects and hence disaster education in their communities.

\section{Acknowledgements}

The researchers would like to thank Bindura University Research and Postgraduate centre for financial assistance.

\section{REFERENCES}

[1] E. Calixto and E.L Larouvere, The regional emergency plan requirement: Application of the best practices to the Brazilian case, Safety Science 48 ,2010, 991-999.

[2] B. V. Ramabrahmam and G. Swaminathan, Disaster management plan for chemical process industries. Case study: investigation of release of chlorine to atmosphere, Journal of Loss Prevention in the Process Industries, 13, 2000, 57-62

[3] B. Woodcock and Z. Au, Human factors issues in the management of emergency response at high hazard installations, Journal of Loss Prevention in the Process Industries, 26, 2013, 766-770.

[4] J. E. Skogdalen, J. Khorsandi, J. E. Vinnem, Evacuation, escape, and rescue experiences from offshore accidents including the Deepwater Horizon, Journal of Loss Prevention in the Process Industries, 25, 2012, 148-158

[5] UNDP 1992, An Overview of Disaster Management 2nd Edition, Disaster Management Training Programme accessed on 10/06/13availablehttp://iaemeuropa.terapad.com/resources/8959/assets/documents/UN\%20DMTP\%20\%200verview\%20of\%20DM.pdf

[6] B V. Ramabrahmam and M. M. Mallikarjunan, Model off-site emergency plan. Case study: toxic gas release from a fertilizer, Journal of Loss Prevention in the Process Industries, 8( 6), 1995, 343-348

[7] G.L. Chikoto. and A. Sadiq. (2012). “Zimbabwe's Emergency Management System: A Promising Development.” Comparative Emergency Management: Understanding Disaster Policies, Organizations, and Initiatives from Around the World. Edited by David McEntire. Accessed on 08/06/13 Published online at: http://www.training.fema.gov/EMIWeb/edu/CompEmMgmtBookProject.asp.

[8] The Civil Protection Act. (2001). Zimbabwe Act: Civil Protection. Parliament of Zimbabwe Document (Chapter No.5, pp. 18). Harare, Zimbabwe. Accessed on 08/06/13 available: http://www.zimdrm.gov.zw/documents?download=7:civil-protection-actchapter-10-06-zimbabwe

[9] D. McAlister and L.Werndle, Leach tank incident at Freda Rebecca gold mine accessed on 08/06/13 available http://www.mwanaafrica.com/investors-and-media/news-releases/2013/leach-tank-incident-at-freda-rebecca-gold-mine-02-14-2013

[10] A. Mushonga, Typhoid outbreak in Bindura City,Zimbabwe: Emergency Response, accessed on 19/06/2013, available: http://internationalmedicalcorps.org/sslpage.aspx?pid=2309

[11] The Chronicle (21 February 2013) accessed on 06/08/13, available:

http://www.chronicle.co.zw/index.php?option=com_content\&view=article\&id=46785:freda-mine-fined-5-000-for-spillingcyanide- \&catid=41:business\&Itemid=133\#.UbIhhvk3CQc

[12] Wikipedia accessed on 18/06/13 available http://en.wikipedia.org/wiki/Sodium_cyanide 18/06/2013

[13] H. Seppänen, J. Mäkelä, P. Luokkala. And K.Virrantaus, Developing shared situational awareness for emergency management , Safety Science ,55,2013, 1-9.

[14] Wikipedia accessed on 18/06/13, available :http://wikipedia.org/wiki/Chernobyl_disaster 